\title{
GAGE4 Gene
}

National Cancer Institute

\section{Source}

National Cancer Institute. GAGE4 Gene. NCI Thesaurus. Code C104483.

This gene may be involved in tumor malignancy. 